\title{
Soybean oil and linseed grains on performance and carcass characteristics of crossbred bulls finished in feedlot
}

\section{Óleo de soja e grãos de linhaça sobre o desempenho e características de carcaça de bovinos cruzados terminados em confinamento}

\author{
Roberto Haruyoshi Ito ${ }^{1}$; Taciana Ducatti ${ }^{1}$; Juliana Martin do Prado ${ }^{1}$; \\ Ivor Martin do Prado ${ }^{1}$; Polyana Pizzi Rotta ${ }^{1}$; Maribel Velandia Valero ${ }^{1}$; \\ Ivanor Nunes do Prado ${ }^{1 *}$; Robério Rodrigues Silva ${ }^{2}$
}

\begin{abstract}
This experiment was carried out to study soybean oil and linseed as feeding alternatives to improve the animal performance and the carcass characteristics of crossbred bulls finished in feedlot for 105 days. There were used 21 bulls with 18 months old randomized in three treatments $(n=7)$ : control (CON) which offered concentrate based on corn; soybean oil + linseed grains (LS1); soybean oil + linseed grains (LS2) that had an experimental time divided in two periods: 60 days with soybean oil and the remaining 45 days with soybean oil + linseed grains. No differences $(\mathrm{P}>0.05)$ were observed among treatments on the initial body weight $(343 \mathrm{~kg})$, final body weight $(501 \mathrm{~kg})$, average daily gain $(1.50 \mathrm{~kg})$, hot carcass weight $(262 \mathrm{~kg})$, carcass dressing $(52.4 \%)$, fat thickness $(5.40 \mathrm{~mm})$, Longissimus area $(88.0$ $\left.\mathrm{cm}^{2}\right)$, Longissimus area/100 $\mathrm{kg}\left(33.7 \mathrm{~cm}^{2}\right)$ dry matter conversion $(8.00 \mathrm{~kg} \mathrm{DM} / 1 \mathrm{~kg}$ of body weight), dry matter intake $(11.8 \mathrm{~kg})$, dry matter intake/live body weight $(2.80 \%)$, crude protein intake $(1.20 \mathrm{~kg})$, gross energy intake (52.9 Mcal/day), acid detergent fiber intake $(2.30 \mathrm{~kg}$ ), acid detergent fiber intake $/ 100 \mathrm{~kg}$ of live body weight $(0.50 \%)$, neutral detergent fiber intake $(2.38 \mathrm{~kg})$ and neutral detergent fiber intake $/ 100$ $\mathrm{kg}$ of live body weight $(0.90 \%)$. Therefore, soybean oil and linseed can be used to replace corn in beef cattle diets without reducing the animal performance and the carcass characteristics.
\end{abstract}

Key words: Average daily gain, beef cattle, dry matter conversion, energy intake

\section{Resumo}

Este experimento foi realizado para estudar o óleo de soja e grãos de linhaça como alimentos alternativos na alimentação animal para melhorar o desempenho e as características de carcaça de animais inteiros cruzados e terminados em confinamento por 105 dias. Foram utilizados 21 animais inteiros com 18 meses de idade distribuídos em três tratamentos $(n=7)$ : controle $(\mathrm{CON})$, onde foi oferecido concentrado a base de milho; óleo de soja + grãos de linhaça (LS1) e óleo de soja + grãos de linhaça (LS2), onde o período experimental foi dividido em duas etapas: 60 dias com óleo de soja e 45 dias com óleo de soja e grãos de linhaça. Não houve diferença $(\mathrm{P}>0,05)$ entre os tratamentos para peso inicial $(343 \mathrm{~kg})$, peso final $(501 \mathrm{~kg})$, ganho médio diário $(1,50 \mathrm{~kg})$, peso da carcaça quente $(262 \mathrm{~kg})$, rendimento de carcaça $(52,4 \%)$, gordura de cobertura $(5,40 \mathrm{~mm})$, área de olho de lombo do Longissimus $\left(88,0 \mathrm{~cm}^{2}\right)$, área de olho de lombo do Longissimus $/ 100 \mathrm{~kg}\left(33,7 \mathrm{~cm}^{2}\right)$, conversão de matéria seca (MS) $(8,00 \mathrm{~kg} \mathrm{MS} / 1 \mathrm{~kg}$ peso vivo), ingestão de matéria seca $(11,8 \mathrm{~kg})$, ingestão de matéria seca/peso vivo $(2,80 \%)$, ingestão de proteína bruta $(1,20 \mathrm{~kg})$, ingestão de energia $(52,9 \mathrm{Mcal} / \mathrm{dia})$, ingestão de fibra em detergente ácido/100

\footnotetext{
1 Animal Science Department, State University of Maringá, Av. Colombo 5790, CEP 87020-900, Maringá, PR, Brazil. E-mail: haruito@gmail.com.br

2 Professor of Animal Science Department, State University of Southwest of Bahia and Post Doctor Fellowship of CNPq. E-mail: inprado@uem.br

* Corresponding Author.
} 
$\mathrm{kg}$ de peso vivo $(0,50 \%)$, ingestão de fibra em detergente neutro $(2,38 \mathrm{~kg})$ e ingestão de fibra em detergente neutro/100 kg de peso vivo $(0,90 \%)$. Dessa forma, óleo de soja e grãos de linhaça podem ser utilizados para substituir o milho em dietas para bovinos inteiros sem que haja alteração no desempenho animal e nas características de carcaça.

Palavras-chave: Bovinos de corte, conversão da matéria seca, ganho médio diário, ingestão de energia.

\section{Introduction}

The beef industry has expanding the meat market by producing some competitive products based on differential aspects of quality. In this way, the maximum performance has been required for achieving such purpose and animals have been slaughtered earlier for obtaining a tender and low fat meat that is very much healthy to customers (MACEDO et al., 2008; PRADO et al., 2008a; b; c; d; DUCATTI et al., 2009; PRADO et al., 2009a; b; c). In this away, highly caloric feed sources have also appeared as an alternative to the traditional components (MULLER et al., 2008).

Meat is considered one of the factors that may lead to the development of human cardiovascular diseases, obesity, hypertension and cancer, especially due to the presence of saturated fat and cholesterol. Low presence of fat contents (less than 3\% relative to muscle) (MOREIRA et al., 2003; PADRE et al., 2006, 2007; ROTTA et al., 2009a; b) and low cholesterol contents (less than $50 \mathrm{mg} 100 \mathrm{~g}^{-1}$ in the muscle) have been observed in meat chemical analyses, ranging from one-third to one-half of the daily recommended cholesterol intake (GREGHI et al., 2003; PADRE et al., 2006, 2007).

Feedlot has been a cost effective alternative for raising beef cattle in those regions where either the grassland price or dietary components are inflating the operating costs. Consequently, both conditions require the use of intensive systems to produce meat of high quality (KAZAMA et al., 2008; PRADO et al., 2008a; b; MAGGIONI et al., 2009a; b). Today, the use of cereal grains like corn have usually been the main source of energy in finishing diets but oils and fats can also be used as alternative components (MOREIRA et al., 2005; MULLER et al., 2008).

However, they are more expensive than carbohydrate sources (corn) or any other agriindustrialby-product, a factwhich has compromising, in many cases, their use as energy suppliers for raising beef cattle (MOREIRA et al., 2005).

Nevertheless, these lipid sources have had strong influence in rumen fermentation because they compromise the cellulolytic activity of microorganisms and reduce the animal performance when offered in large quantities. Today, the use of conventional sources of fat on beef cattle diets has still been small (HIGHTSHOE et al., 1991) because some papers (ANDRAE et al., 2000; ENGLE et al., 2000) have described reducing effects on the intake and in the efficiency of fiber digestion although such effects depend on the way fat is offered to the animals. In such way, vegetal oils are strong inhibitors of microorganisms' activity in comparison to animal fat because they are more unsaturated.

The high average gain of $2.00 \mathrm{~kg} /$ day were reported by Andrae et al. (2000) who fed 60 crossbred steers with $82.0 \%$ of corn $+12.0 \%$ of triticale silage, $82.0 \%$ of high oil corn $+12.0 \%$ of silage, and highoil corn which were formulated to be iso energetic to the control which had $74.0 \%$ of high oil corn + $20.0 \%$ of silage. On the other hand, Kazama et al. (2008) reported gain of $1.30 \mathrm{~kg} /$ day from crossbred heifers (Bos taurus taurus vs. Bos taurus indicus) finished in feedlot with diets containing $22.0 \%$ of cotton seed hulls, $45.0 \%$ soybean hulls, $7.00 \%$ cotton seed meal, $23.5 \%$ of corn germ meal or rice bran, $0.80 \%$ of mineral salt, $0.80 \%$ limestone and $1.20 \%$ urea. 
Moreover, oil seeds are better as the source of fat because their embryos are efficiently surrounded by the tegument which protects ruminal microorganisms (SOUZA et al., 2007). The use of protected fat like linseed has been studied to promote increases of unsaturated fatty acids like omega-3 and omega-6 which add significant benefits to the human health (ARICETTI et al., 2008).

This experiment was carried out to evaluate the effects of soybean oil with linseed grains on the animal performance and carcass characteristics of crossbred bulls finished in feedlot.

\section{Material and Methods}

\section{Animals and management}

The Committee of Animal Production at State University of Maringá approved this experiment which was carried out at Beef Cattle Section in Iguatemi Research Farm and followed the guiding principles of biomedical research with animals (CIOMS, 1985). Feed samples were analyzed at Laboratory of Feed Analyses and Animal Nutrition at State University of Maringá, Northwestern Paraná, South Brazil.

Twenty one crossbred bulls ( $1 / 2$ Nellore x $1 / 2$ Simmenthal) with average of 18 months old and initial body weight of $343 \mathrm{~kg}$ were previously identified and kept separate into $10 \mathrm{~m}^{2}$ pens for 105 days. Each pen was fenced with steel poles and protected by concrete floor. Fifty percent of the area was covered by zinc roof under which were placed troughs with $2 \mathrm{~m}$ in length. Water tanks with the volume of 250 liters were set up on the opposite side. The animals were accommodated to the experimental conditions for 10 days when they were wormed and supplemented with ADE vitamin.

\section{Experimental diets}

There were used 21 animals randomized in three treatments $(n=7)$ : control $(\mathrm{CON})$ which offered concentrate based on corn; soybean oil + linseed grains (LS1); soybean oil + linseed grains (LS2) that had an experimental time divided in two periods: 60 days with soybean oil and the remaining 45 days with soybean oil + linseed grains (Table 1).

Table 1. Composition of the experimental diets $(\mathrm{g} / \mathrm{kg})$.

\begin{tabular}{lccc}
\hline & \multicolumn{3}{c}{ Treatments } \\
\cline { 2 - 4 } Ingredients & $\mathrm{CON}^{\mathrm{a}}$ & OIL1 $^{\mathrm{b}}$ & OIL2 $^{\mathrm{c}}$ \\
\hline Corn silage & 566 & 723 & 724 \\
Ground corn grain & 398 & 179 & 179 \\
Linseed & --- & 47.0 & 47.0 \\
Soybean oil & --- & 20.0 & 20.0 \\
Soybean meal & 23.0 & 18.0 & 18.0 \\
Limestone & 4.00 & 4.00 & 4.00 \\
Mineral salts & 4.00 & 4.00 & 4.00 \\
Urea & 4.00 & 5.00 & 4.00 \\
\hline
\end{tabular}

${ }^{\mathrm{a}}$ Control, ${ }^{\mathrm{b}}$ Soybean oil + linseed (105d), ${ }^{\mathrm{c} S}$ Soybean oil (60d) + linseed (45 d).

These diets were formulated to be isonitrogenous and iso-energetic and followed the recommendations of the NRC (1996) to achieve the body weight gain of $1.30 \mathrm{~kg} /$ day. The dietary supplement was stipulated to allow the possibility of $5 \%$ of refusal in the trough. The complete diets (roughage + concentrate) were daily offered at 8:00 am and 04:00 pm. The chemical composition of ingredients and experimental diets are presented in (Table 2). 
Ito, R. H. et al.

Table 2. Chemical composition of ingredients and experimental diets $(\mathrm{g} / \mathrm{kg})$.

\begin{tabular}{|c|c|c|c|c|c|c|c|c|}
\hline \multirow[b]{2}{*}{ Ingredients } & \multirow[b]{2}{*}{$\mathrm{DM}^{\mathrm{a}}$} & \multicolumn{7}{|c|}{$\mathrm{g} / \mathrm{kg}$} \\
\hline & & $\mathrm{MM}^{\mathrm{b}}$ & $\mathrm{OM}^{\mathrm{c}}$ & $\mathrm{CP}^{\mathrm{d}}$ & $\mathrm{NDF}^{\mathrm{e}}$ & $\mathrm{ADF}^{\mathrm{f}}$ & $\mathrm{GE}^{\mathrm{g}}$ & $\mathrm{EE}^{\mathrm{h}}$ \\
\hline Corn silage & 335 & 46.0 & 954 & 75.0 & 457 & 294 & 44.4 & 30.5 \\
\hline Ground corn grains & 891 & 10.4 & 990 & 80.0 & 126 & 31.1 & 43.2 & 37.0 \\
\hline Linseed & 935 & 34.5 & 966 & 231 & 484 & 348 & 65.0 & 404 \\
\hline Soybean oil & 998 & --- & --- & --- & --- & --- & 97.3 & 1000 \\
\hline Soybean meal & 886 & 49.1 & 951 & 508 & 150 & 111 & 47.1 & 18.0 \\
\hline Limestone & 999 & 995 & 4.60 & --- & --- & --- & --- & --- \\
\hline Mineral salts & 987 & 899 & 107 & --- & --- & --- & --- & --- \\
\hline Urea & 988 & --- & --- & 2736 & --- & --- & --- & --- \\
\hline $\mathrm{CON}^{\mathrm{i}}$ & 577 & 38.9 & 956 & 99.6 & 313 & 181 & 43.4 & 32.4 \\
\hline $\mathrm{LS} 1^{\mathrm{j}}$ & 494 & 45.2 & 930 & 102. & 379 & 237 & 45.7 & 69.0 \\
\hline $\mathrm{LS} 2^{\mathrm{k}}$ & 533 & 41.7 & 933 & 98.9 & 338 & 203 & 44.6 & 51.1 \\
\hline
\end{tabular}

${ }^{\mathrm{a}}$ Dry matter, ${ }^{\mathrm{b}}$ Mineral matter, ${ }^{\mathrm{c}}$ Organic matter, ${ }^{\mathrm{d}}$ Crude protein, ${ }^{\mathrm{e}}$ Neutral detergent fiber, ${ }^{\mathrm{f}}$ Acid detergent fiber, ${ }^{\mathrm{g}} \mathrm{Mcal} / \mathrm{kg}$ DM, ${ }^{\text {h} E t h e r ~ e x t r a c t, ~}{ }^{i}$ Control, ${ }^{j}$ Soybean oil + linseed (105), ${ }^{k}$ Soybean oil (60d) + linseed (45 d).

The animals were weighed at trial entry and every 28 day interval before the first feeding. The feed intake was recorded daily by weighing leftovers every morning. Feed diets and leftovers, dry matter, organic matter, crude protein, ether extract, gross energy, neutral detergent fiber and acid detergent fiber were determined according to Silva and Queiroz (2002).

\section{Carcass evaluation}

The animals were slaughtered at a commercial slaugther $50 \mathrm{~km}$ from the Iguatemi Research Farm following the usual practice of the Brazilian beef industry where the carcasses were weighed, indentified, and chilled at $2^{\circ} \mathrm{C}$ for 24 hours. Samples were collected by taking a complete cross section between the $12^{\text {th }}$ and $13^{\text {th }}$ rib and were immediately delivered at the laboratory facilities for evaluating the fat thickness and Longissimus area.

A micrometer of high precision was used to determine fat thickness; the final result was an average of three measurements (mm). The Longissimus area was accomplished by using vegetal paper where the diameter of the muscle was reproduced and the area $\left(\mathrm{cm}^{2}\right)$ was taken by the planimeter method.

\section{Statistical analysis}

It was used a complete randomized design with three treatments and seven replicates. The data were analyzed using the SAS Software (SAS, 2000), following the model $\mathrm{Y}_{\mathrm{ij}}=\mu+\mathrm{t}_{\mathrm{i}}+\mathrm{e}_{\mathrm{ij}}$ in which $\mathrm{Y}_{\mathrm{ij}}=$ record of the $j$ animal submitted to the $i$ treatment; $\mu=$ general constant; $\mathrm{t}_{\mathrm{i}}=$ the effect from the $i$ treatment; $\mathrm{i}$ $=1,2,3 ; \mathrm{e}_{\mathrm{ij}}=$ random error associated to the $Y_{i j}$ record. Significant differences were evaluated by the Tukey test at the level of $5 \%$ of probability.

\section{Results and discussion}

\section{Animal performance}

No difference $(\mathrm{P}>0.05)$ among treatments were observed for the following variables: initial body weight (IBW), final body weight (FBW), average daily gains (ADG), dry matter feed conversion (DMC), dry matter intake (DMI), dry matter intake/ live body weight (DMI/LW), crude protein intake (CPI), gross energy intake (GEI), acid detergent fiber intake (ADFI), acid detergent fiber intake/100 $\mathrm{kg}$ of live body weight (ADFI/100 kg LW), neutral detergent fiber intake (NDFI) and neutral detergent fiber intake/100 $\mathrm{kg}$ of live body weight (NDFI/100 kg LW) (Table 3). 
Table 3. Performance of crossbred cattle finished in feedlot.

\begin{tabular}{lccccc}
\hline & \multicolumn{3}{c}{ Treatments } & & \\
Parameters & CON $^{\mathrm{a}}$ & LS1 $^{\mathrm{b}}$ & LS2 $^{\mathrm{c}}$ & $\mathrm{SE}^{\mathrm{d}}$ & $\mathrm{P}<\mathrm{F}$ \\
\hline Initial body weight, $\mathrm{kg}$ & 345 & 341 & 343 & 10.0 & $\mathrm{~ns}$ \\
Final body weight, kg & 512 & 492 & 499 & 14.5 & $\mathrm{~ns}$ \\
Average daily gain, kg/day & 1.60 & 1.40 & 1.50 & 0.08 & $\mathrm{~ns}$ \\
Dry matter conversion (DMC) & 7.90 & 8.10 & 7.90 & 0.41 & $\mathrm{~ns}$ \\
Dry matter intake (DMI), kg/day & 12.6 & 11.4 & 11.4 & 0.38 & $\mathrm{~ns}$ \\
DMI/live body weigh, \% & 2.94 & 2.70 & 2.70 & 0.08 & $\mathrm{~ns}$ \\
Crude protein intake, kg & 1.30 & 1.20 & 1.10 & 0.04 & $\mathrm{~ns}$ \\
Gross energy intake, Mcal/day & 54.9 & 52.1 & 51.8 & 1.73 & $\mathrm{~ns}$ \\
Acid detergent fiber intake (ADFI), kg & 2.30 & 2.30 & 2.20 & 0.07 & $\mathrm{~ns}$ \\
ADFI/100 kg of live body weight, \% & 0.60 & 0.60 & 0.50 & 0.01 & $\mathrm{~ns}$ \\
Neutral detergent fiber intake (NDFI), kg & 4.00 & 3.90 & 3.60 & 0.12 & $\mathrm{~ns}$ \\
NDFI /100 kg of live body weight, \% & 0.90 & 0.90 & 0.90 & 0.03 & $\mathrm{~ns}$ \\
\hline
\end{tabular}

${ }^{\mathrm{a}}$ Control, ${ }^{\mathrm{b}}$ Soybean oil + linseed, ${ }^{\mathrm{c}}$ Soybean oil $(60 \mathrm{~d})+$ linseed $(45 \mathrm{~d}),{ }^{\mathrm{d}}$ Coefficient of variation.

The average of initial and final live body weight was $343 \mathrm{~kg}$ and $501 \mathrm{~kg}$, respectively. Prado et al. (1995) reported $400 \mathrm{~kg}$ of final live body weight for Nellore steers. Furthermore, the average daily gain of $1.50 \mathrm{~kg}$ /day was satisfactory. Additionally, these results are consistent with Aferri et al. (2005) who reported the gain of $1.20 \mathrm{~kg} /$ day and similar to Beaulieu et al. (2002) who reported $1.50 \mathrm{~kg}$ /day for 102 days unlike the highest average gain of $2.00 \mathrm{~kg} /$ day reported by Andrae et al. (2000).

The feed conversion had an average of 8.00 $\mathrm{kg}$ of dry matter intake per kilogram of live body weight gain. This result is consistent with the mean of $9.00 \mathrm{~kg}$ reported by Abrahão et al. (2006) who fed 21-month-old Nellore heifers with linseed and canola grains, and Aferri et al. (2005) who reported the mean value of $8.09 \mathrm{~kg}$.

The mean intake of dry matter and dry matter intake/live body weight was $11.8 \mathrm{~kg} /$ day and $2.80 \%$, respectively. However, Aferri et al. (2005) reported $8.90 \mathrm{~kg} /$ day and $2.30 \%$. Reduction of dry matter intake due to increases of fat in the beef cattle diet was not reported by Zinn et al. (2000) who detected mean values of $1.87 \%$ of dry matter intake/live body weight. Similar results were also observed by
Prado et al. (1995) who reported 3.23\% and 2.52\% for $15.0 \%$ and $30.0 \%$ of cottonseed, respectively. On the other hand, Ngidi et al. (1990) found that the protected fat reduced the dry matter intake to 7.80 and $6.90 \mathrm{~kg} / \mathrm{animal} /$ day for level of 4.00 and $6.00 \%$, respectively.

The present results showed that soybean oil + linseed did not reduce dry matter intake and the animal performance. Positive effects on the animal performance occur because this diet offers no more than $7.00 \%$ of ether extract which avoids damages in cellulolytic activities of micro-organisms (VAN SOEST, 1994).

The mean value of crude protein intake was 1.20 $\mathrm{kg} /$ animal/day unlike $1.00 \mathrm{~kg} / \mathrm{animal} /$ day reported by Abrahão et al. (2006). Such results were found satisfactory due to the animal performance in the present trial.

The mean values of acid detergent fiber intake and acid detergent fiber intake by $100 \mathrm{~kg}$ of live body weight was $2.30 \mathrm{~kg} /$ animal $/$ day and $0.50 \%$. Neutral detergent fiber intake and neutral detergent fiber intake by $100 \mathrm{~kg}$ of live body weight was 3.80 $\mathrm{kg} /$ animal/day and $0.90 \%$, respectively. 


\section{Carcass evaluation}

No difference $(\mathrm{P}>0.05)$ in hot carcass weight (HCW), carcass dressing (CD), fat thickness (FT),
Longissimus area (LA) and Longissimus area/100 kg of carcass weight (LA/100 $\mathrm{kg} \mathrm{CW}$ ) were observed in this experiment (Table 4).

Table 4. Carcass evaluation of crossbred cattle finished in feedlot.

\begin{tabular}{|c|c|c|c|c|c|}
\hline \multirow[b]{2}{*}{ Parameters } & \multicolumn{3}{|c|}{ Treatments } & \multirow[b]{2}{*}{$\mathrm{SE}^{\mathrm{d}}$} & \multirow[b]{2}{*}{$\mathrm{P}<\mathrm{F}$} \\
\hline & $\mathrm{CON}^{\mathrm{a}}$ & $\mathrm{LS}^{\mathrm{b}}{ }^{\mathrm{b}}$ & $\mathrm{LS}^{\mathrm{c}}$ & & \\
\hline Hot carcass weight, $\mathrm{kg}$ & 267 & 256 & 261 & 6.79 & ns \\
\hline Carcass dressing, $\%$ & 52.7 & 52.1 & 52.3 & 0.47 & ns \\
\hline Fat thickness, mm & 5.70 & 5.50 & 5.00 & 0.42 & ns \\
\hline Longissimus area, $\mathrm{cm}^{2}$ & 92.2 & 87.2 & 84.7 & 3.53 & ns \\
\hline Longissimus area/100 kg & 34.1 & 34.3 & 34.0 & 1.25 & ns \\
\hline
\end{tabular}

${ }^{\mathrm{a}}$ Control, ${ }^{\mathrm{b}}$ Soybean oil + linseed, ${ }^{\mathrm{c}}$ Soybean oil $(60 \mathrm{~d})+$ linseed $(45 \mathrm{~d}),{ }^{\mathrm{d}}$ Coefficient of variation.

Furthermore, there are various factors affecting the carcass dressing like breeds and feed components. The mean value of $52.4 \%$ was similar to Prado et al. (2008b) (52.2\%), but different of Prado et al. (2000) (57.3\%) and Abrahão et al. (2005) (54.8\%).

Additionally, it was observed a mean value of $5.40 \mathrm{~mm}$ for fat thickness which is within Brazilian standards that range from 3.00 to $6.00 \mathrm{~mm}$. Feeding has strongly been influencing the animal finishing because it affects the percentage of fat that accumulates into carcass and muscles. Consequently, animals submitted to different feeding levels and slaughtered at the same age have their carcasses with different fat content (WEBB, 2006; ROTTA et al., 2009b). The fat thickness acts like a thermal insulator protecting the carcass from cold shrinking during the cooling which requires a minimum of fat thickness to guarantee superior meat quality.

Satisfactory mean values of the Longissimus area (LA) and the Longissimus area/100 $\mathrm{kg}$ of carcass weight (LA/100 $\mathrm{kg} \mathrm{CW}$ ) was $88.0 \mathrm{~cm}^{2}$ and 33.7 , respectively. The mean values of the Longissimus area and the fat thickness are related to the quantity of muscles; consequently, high fat indicates less muscle and worst lean carcasses. Fat thickness has been the main external indicator of carcass finishing because it has been an important trait to determine the slaughtering age (WEBB, 2006).

\section{Conclusion}

The replacement of corn by soybean oil in conjunction with linseed grains did not affect the animal performance and the carcass characteristics of crossbred bulls ( $1 / 2$ Nellore x $1 / 2$ Simmenthal) finished in feedlot. If cost effective, soybean oil and linseed grains would be a feed alternative in beef cattle diets.

\section{Acknowledgments}

This study was supported by the Araucaria Foundation and Brazilian Council for Research and Technological Development (CNPq).

\section{References}

ABRAHÃO, J. J.; PRADO, I. N.; MARQUES, J. A.; PEROTTO, D.; LUGÃO, S. M. B. Effects of replacing corn with dry cassava byproducts on production of feedlot crossbred heifers. Brazilian Journal of Animal Science, Viçosa, v. 35, n. 2, p. 512-516, 2006.

ABRAHÃO, J. J.; PRADO, I. N.; PEROTTO, D.; MOLETTA, J. L. Effects of replacing corn with increasing levels of cassava starch by-products on carcass characteristics and meat for young bulls. Brazilian Journal of Animal Science, Viçosa, v. 34, n. 5, p. 16401650, 2005. 
AFERRI, G.; LEME, P. R.; SILVA, S. L.; PUTRINO, S. M.; PEREIRA, A. S. M. Performance and carcass characteristics of steers fed different fat sources. Brazilian Journal of Animal Science, Viçosa, v. 34, n. 5, p. 16511658, 2005.

ANDRAE, J. G.; HUNT, C. W.; DUCKETT, S. K.; KENNINGTON, L. R. P.; FENG, F. N. Effect of high-oil corn growth performance, diet digestibility, and energy content of finishing diets fed to beef cattle. Journal of Animal Science, Savoy, v. 78, n. 9, p. 2257-2262, 2000.

ARICETTI, J. A.; ROTTA, P. P.; PRADO, R. M.; PEROTTO, D.; MOLETTA, J. L.; MATSUSHITA M.; PRADO, I. N. Carcass characteristics, chemical composition and fatty acid profile of Longissimus muscle of bulls and steers finished in a pasture system. AsianAustraliasian Journal of Animal Science, Seoul, v. 21, n. 10, p. 1441-1448, 2008.

BEAUlIEU, A. D.; DRACKLEY, J. K.; MERCHEN, N. R. Concentrations of conjugated linoleic acid (cis-9, trans11-octadecadienoic acid) are not increased in tissue lipids of cattle fed a high-concentrate diet supplemented with soybean oil. Journal of Animal Science, Savoy, v. 80, n. 3, p. 847-861, 2002.

CIOMS/OMS. Council for International Organizations of Medical Sciences. WHO Distribution and Sales Service, 1211 Geneva 27, Switzerland, International Guiding Principles for Biomedical Research Involving Animals, 1985.

DUCATTI, T.; PRADO, I. N.; ROTTA, P. P.; PRADO, R. M.; PEROTTO, D.; MAGGIONI, D.; VISENTAINER, J. V. Chemical composition and fatty acid profile in crossbred (Bos taurus vs. Bos indicus) young bulls finished in a feedlot. Asian-Australasian Journal of Animal Science, Seoul, v. 22, n. 3, p. 433-439, 2009.

ENGLE, T. E.; SPEARS, J. W.; FELLNER, V.; ODLE, J. Effects of soybean oil and dietary copper on ruminal and tissue lipid metabolism in finishing steers. Journal of Animal Science, Savoy, v. 78, n. 10, p. 2713-2721, 2000.

GREGHI, M. E.; VIEIRA, F. C.; RUIZ, N.; VISENTAINER, J. V.; PRADO, I. N.; SOUZA, N. E. Effects of slaughter weight on the muscle fatty acids composition of subcutaneous and intramuscular lipids of Dutch steers. In: ASSOCIAÇÃO BRASILEIRA DE QUÍMICA, São Paulo, 2003. Campinas. Anais... Campinas: Associação Brasileira de Química, v. 52, n. 1, p. 129-133, 2003.

HIGHTSHOE, R. B.; COCHRAN, R. C.; CORAH, L. R.; HARMON, D. L.; VANZANT, E. S. Influence of source and level of ruminal-escape lipid in supplements on forage intake, digestibility, digesta flow, and fermentation characteristics in beef cattle. Journal of Animal Science, Savoy, v. 69, n. 12, p. 4974-4982, 1991.

KAZAMA, R.; ZEOULA, L. M.; PRADO, I. N.; SILVA, D. C.; DUCATTI, T.; MATSUSHITA, M. Quantitative and qualitative carcass characteristics of heifers fed different energy sources on a cottonseed hulls and soybean hulls based diet. Brazilian Journal of Animal Science, Viçosa, v. 37, n. 2, p. 350-357, 2008.

MACEDO, L. M. A.; PRADO, I. M.; PRADO, J. M.; ROTTA, P. P.; PRADO, R. M.; SOUZA, N. E.; PRADO, I. N. Chemical composition and fatty acids profile of five carcass cuts of crossbred heifers finished in feedlot. Semina, Londrina, v. 29, n. 3, p. 597-608, 2008.

MAGGIONI, D.; MARQUES, J. A.; PEROTTO, D.; ROTTA, P. P.; DUCATTI, T.; MATSUSHITA, M.; SILVA, R. R.; PRADO, I. N. Bermuda grass hay or sorghum silage with or without yeast addition on performance and carcass characteristics of crossbred young bulls finished in feedlot. Asian-Australasian Journal of Animal Science, Seoul, v. 22, n. 2, p. 206-215, 2009a.

MAGGIONI, D.; MARQUES, J. A.; ROTTA, P. P.; PEROTTO, D.; DUCATTI, T.; VISENTAINER, J. V.; PRADO, I. N. Animal performance and meat quality of crossbred young bulls. Livestock Science, Amsterdam, In Press, 2009b.

MOREIRA, F. B.; PRADO, I. N.; SOUZA, N. E.; MATSUSHITA, M.; MIZUBUTI, I. Y.; MACEDO, L. M. Animal performance and carcass characteristics of steers finished in black oat pasture with or without energetic supplement. Acta Scientiarum, Animal Science, Maringá, v. 27, n. 4, p. 469-473, 2005.

MOREIRA, F. B.; SOUZA, N. E.; MATSUSHITA, M.; PRADO, I. N.; NASCIMENTO, W. G. Evaluation of carcass characteristics and meat chemical composition of Bos indicus and Bos indicus x Bos taurus crossbred steers finished in pasture systems. Brazilian Archives of Biology and Technology, Curitiba, v. 46, n. 4, p. 609-616, 2003.

MÜLLER, M.; LOBO JÚNIOR, A. R.; PRADO, I. N.; SILVA, R. R.; CAPOVILlA, L. C. T.; RIGOLON, L. P.; CAVALIERI, F. L. B. Fontes de gordura ômega 3 e ômega 6 sobre o desempenho, resposta superovulatória e produção de embriões em nelore. Archivos de Zootecnia, Cordova, v. 58, n. 222, p. 241-252, 2009.

NATIONAL RESEARCH COUNCIL - NRC. Nutrients requirements of beef cattle. 7. ed. Washington, D.C.: National Academy Press, 1996. 244 p.

NGIDI, M. E.; LOERCH, S. C.; FLUHARTY, F. L.; PALMQUIST, D. L. Effects of calcium soaps of longchain fatty acids on feedlot performance, carcass 
characteristics and ruminal metabolism of steers. Jounal of Animal Science, Savoy, v. 68, n. 8, p. 2555-2565, 1990.

PADRE, R. G.; ARICETTI, J. A.; MOREIRA, F. B.; MIZUBUTI, I. Y.; PRADO, I. N.; VISENTANIER, J. V.; SOUZA, N. E.; MATSUSHITA, M. Fatty acids profile, and chemical composition of Longissimus muscle of bovine steers and bulls finished in pasture system. Meat Science, Oxon, v. 74, n. 1, p. 242-248, 2006.

PADRE, R. G.; ARICETTI, J. A.; GOMES, S. T. M.; GOES, R. H. T. B.; MOREIRA, F. B.; PRADO, I. N.; VISENTAINER, J. V.; SOUZA, N. E.; MATSUSHITA, M. Analysis of fatty acids in Longissimus muscle of steers of different genetic breeds finished in pasture systems. Livestook Science, v. 110, n. 1, p. 57-63, 2007.

PRADO, I. N.; BRANCO, A. F.; ZEOULA, L. M.; PINTO, A. A.; MORAES, G. V.; MOREIRA, H. L. M. Desempenho e características de carcaça de bovinos Nelore confinados, recebendo 10 ou $30 \%$ de caroço integral de algodão, bagaço auto hidrolisado de cana-deaçúcar e cana de açúcar ou capim elefante. Arquivos de Biologia e Tecnologia, Curitiba, v. 38, n. 2, p. 353-365, 1995.

PRADO, I. N.; PINHEIRO, A. D.; ALCALDE, C. R.; ZEOULA, L. M.; NASCIMENTO, W. G.; SOUZA, N. E. Níveis de substituição de milho pela polpa de citrus peletizada sobre o desempenho e características de carcaça de bovinos mestiços confinados. Brazilian Journal of Animal Science, Viçosa, v. 29, n .6, p. 21352141, 2000.

PRADO, I. N.; ITO, R. H.; PRADO, J. M.; PRADO, I. M.; ROTTA, P. P.; MATSUSHITA, M.; VISENTAINER, J. V.; SILVA, R. R. The influence of dietary soyabean and linseed on the chemical composition and fatty acid profile of the Longissimus muscle of feedlot-finished bulls. Journal of Animal and Feed Science, Jablonna, v. 17, n. 3, p. 307-317, 2008a.

PRADO, I. N.; PRADO R. M.; ROTTA, P. P.; VISENTAINER, J. V.; MOLETTA, J. L.; PEROTTO, D. Carcass characteristics and chemical composition of the Longissimus muscle of crossbred bulls (Bos taurus indicus vs Bos taurus taurus) finished in feedlot. Journal of Animal and Feed Science, Jablonna, v. 17, n. 3, p. $295-$ 306, 2008b.

PRADO, I. N.; ROTTA, P. P.; PRADO, R. M.; VISENTAINER, J. V.; MOLETTA, J. L.; PEROTTO, D. Carcass characteristics and chemical composition of the Longissimus muscle of Purunã and 1/2 Puruna vs. 1/2 Canchin bulls. Asian-Australasian Journal of Animal Science, Seoul, v. 21, n. 9, p. 1296-1302, 2008 c.
PRADO, I. N.; ARICETTI, J. A.; ROTTA, P. P.; PRADO, R. M.; PEROTTO, D.; VISENTAINER, J. V.; MATSUSHITA, M. Carcass characteristics, chemical composition and fatty acid profile of the Longissimus muscle of bulls (Bos Taurus indicus vs. Bos Taurus Taurus) finished in pasture systems. Asian-Australiasian Journal of Animal and Science, Seoul, v. 21, n. 10, p. 1449-1457, 2008d.

PRADO, J. M.; PRADO, I. N.; VISENTAINER, J. V.; ROTTA, P. P.; PEROTTO, D.; MOLETTA, J. L.; PRADO, I. M.; DUCATTI, T. The effect of breed on chemical composition and fatty acid composition on Longissimus dorsi muscle of Brazilian beef cattle. Journal of Animal and Feed Science, Jablonna, v. 18, n. 2, p. 231-240, 2009a.

PRADO, R. M.; PRADO, I. N.; MARQUES, J. A.; ROTTA, P. P.; VISENTAINER, J. V.; SILVA, R. R.; SOUZA, N. E. Meat quality of the Longissimus muscle of bulls and steers ( $1 / 2$ Nellore vs $1 / 2$ Simenthal) finished in feedlot. Journal of Animal and Feed Science, Jablonna, v. 18, n. 2, p. 221-230, 2009b.

PRADO, I. N.; OLIVEIRA, A. N.; ROTTA, P. P.; PEROTTO, D.; PRADO, I. N.; SILVA, R. R.; SOUZA, N. E.; MOLETTA, J. L. Chemical and fatty acid composition of Longissimus muscle of crossbred bulls finished in feedlot. Asian-Austalasian Journal of Animal Science, Seoul, v. 22, n. 7, p. 1054-1059, 2009c.

ROTTA, P. P.; PRADO, I. N.; PRADO, R. M., MOLETTA, J. L.; SILVA, R. R.; PEROTTO, D. Carcass characteristics and chemical composition of the Longissimus muscle of Nellore, Caracu and Holstein-friesian bulls finished in a feedlot. Asian-Australasian Journal of Animal Science, Seoul, v. 22, n. 4, p. 598-604, 2009a.

ROTTA, P. P.; PRADO, R. M.; PRADO, I. N.; VALERO, M. V.; VISENTAINER, J. V.; SILVA, R. R. The effects of genetic groups, nutrition, finishing systems and gender of Brazilian cattle on carcass characteristics and beef composition and appearance: a review. AsianAustralasian Journal of Animal Science, Seoul, v.22, n.12, p.1718-1734, 2009b.

SAS INSTITUTE. SAS/STAT ${ }^{\circledR}$.User's guide: statistics, versão 8.1. 4. ed. Cary: SAS Institute, 2000. v. 2.

SILVA, D. J.; QUEIROZ, A. C. Análise de alimentos (métodos químicos e biológicos). 3. ed., Viçosa, MG: UFV. 2002. 235 p.

SOUZA, N. E.; SILVA, R. R.; PRADO, I. M.; PRADO, J. M.; WADA, F. Y.; PRADO, I. N. Whole Linseed and Canola Seed on Chemical Composition and Fatty Acids Composition of Longissimus dorsi muscle of Nellore 
Heifers in Feedlot. Archivos de Zootecnia, Cordoba, v. 56, n. 216, p. 863-874, 2007.

VAN SOEST, P. J. Nutritional ecology of the ruminant. 2. ed. London: Cornell University Press, 1994. 476 p.

WEBB, E. C. Manipulation beef quality through feeding.
South African Journal of Food Science Nutrition, Jonesburg, v. 7, p. 5-15, 2006.

ZINN, R. A.; GULATI, S. K.; PLASCENCIA, A.; SALINAS, J. Influence of ruminal biohydrogenation on the feeding value of fat in finishing diets for feedlot cattle. Journal Animal Science, Savoy, v. 78, n. 7, p. 1738-1746, 2000. 
